\title{
SUMMARY OF GLUE TESTS 1993
}

David Bell

$1 / 7 / 93$

D-ZERO ENGINEERING NOTE 3823.113-EN-357

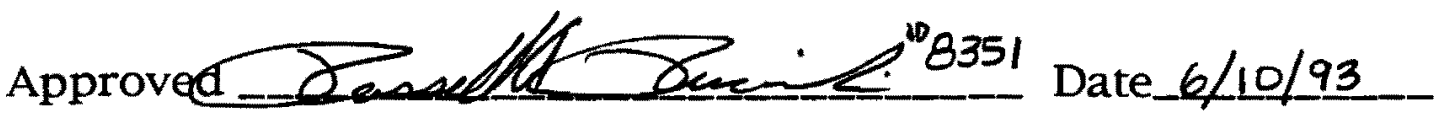




\section{ADHESIVE TESTING RESULTS SUMMARY FALL 1992.}

I have reported most of the results of my adhesive testing to members of the VLPC design team at one time or another, usually verbally, but I am writing this summary as an easy reference to the results I obtained. The adhesives I tested were for two primary purposes. The first was adhering optical fibers to Torlon 7130; the other was for securing an aluminum nitride substrate to the same material. I have not had access to a scanning electron microscope and someone with the knowledge to determine actual failure mechanisms, so the deductions I have made about why some adhesives have worked well at low temperatures for some purposes and not for other applications while a different material never worked and another always worked are partially speculation. They should be taken merely at face value with no particular results "carved in stone" so to speak.

The first aspect of my testing was adhesion of optical fiber to torlon. Knowing that this is a very important joint, I tested a variety of glues of two primary types: acrylic and UV cure. UV cure adhesives are known to possess reasonably good properties at low temperatures and are quite convenient to use as long as a UV source is available. The UV cure adhesives I tested were: Loctite Litak 376 and also 7EN484(?), Master Bond 1 Component UV 15-7, and Norland optical adhesive 61 . I found them quite easy to use, and they were packaged in a way in which they were not likely to cause a mess. Lab 6 experimenters generally used the Loctite 376 optical cure adhesive in their research into connecting scintillating fibers to the standard type. The acrylics I tested were Loctite Speed Bonder 324 and Permabond Quick Bond 610. These worked reasonably well, but they require a considerably longer set time than the UV cure adhesives and are more complicated to use. (5 minutes set time or so for the acrylics versus about 30 seconds for the UV. The Loctite must have the activator applied about 5 minutes prior to the adhesive application and the Permabond must be mixed adequately.) I also used a cyanoacrylate ester (superglue type) adhesive which appeared to function adequately in this test, but I would not recommend it for extended use, and I am certain neither would anyone else. I would highly recommend using a UV curing adhesive for this purpose if the adhesives and the UV treatment can be determined to cause no damage to the fibers. There is no apparent physical damage, but transmission could potentially be damaged. The final optical fiber to torlon test that I did involved testing to see if individual fibers could hold the weight of the entire VLPC copper isotherm in the event that a small number of fibers shrink more than the others as the cryostat is cooled down. While this test was primarily for the purpose of testing the fibers themselves, I constructed a new sample to avoid breaking the others that had already been finished. The adhesive I used for this test was $3 \mathrm{M} 3535 \mathrm{~B} / \mathrm{A}$ two part urethane adhesive. I had no problems whatsoever with this product, but like the other two part adhesives, it is considerably less convenient and more messy than the UV curing adhesives. The short pot life of this adhesive was also a reason to avoid urethane, since mixing would be required frequently.

The other portion of the adhesive testing for the VLPC that I performed was the adhesion of the substrate to the torlon used as a carrier. This bond is extremely small in practice, and I could not completely simulate the size and likely construction methods. I used larger pieces than those that will be bonded, but the primary goal of these tests was to test the performance of the adhesives. These tests contained harsher conditions of temperature changes and loadings than the substrates are likely to meet. By lightly loading the 
substrates before and after the cooling, it is possible to see if the cold temperatures had any effect on the adhesive-torlon interface, the adhesivesubstrate interface, or the adhesive itself. I tested about 10 adhesives intensely. In addition to these tests I also talked to people with about 20 different adhesive manufactures (maybe more) and Jay Hoffman, an adhesive expert here at the Lab. The general consensus from the people that I spoke with is that the temperature range near liquid helium is very harsh and many adhesives that set quickly are not able to withstand these temperatures. Only one of the companies that I spoke with had any experience with temperatures that low (they made adhesives for space applications). I will go over each adhesive used in my testing. In addition, I will describe and speculate on the cause of any failures.

The first two types of adhesives used were 2 part acrylics. The Loctite Speed Bonder 324 required an activator that took about 5 minutes to dry, and then the resin could be applied. The adhesive then required around 5 minutes to set under ambient conditions as did the other 2 part acrylic, Permabond Quick Bond 610. I found that neither of these adhesives had a success rate above $50 \%$ in any of my tests. The Loctite was usually around $25 \%$ to $33 \%$ successful, the Permabond a bit higher. All of my tests involved gluing the substrate pieces to a torlon piece, allowing them to dry at least 12 to 24 hours, lightly trying to pry the substrates off, cooling the samples to liquid helium temperatures, removing, and again trying to lightly pry the samples that remained (if any) off. The materials I used as a substrate included: aluminum nitride (AlN) ceramic and chips, alumina $\left(\mathrm{Al}_{2} \mathrm{O}_{3}\right)$ chips, silicon, silicon carbide ( $\left.\mathrm{SiC}\right)$, and stainless steel. The adhesive remained in contact with the torlon in every bond in each test with these adhesives; the failure in nearly every instance occurred at the interface between the ceramic and the adhesive or the metal and the adhesive. There were only two instances where this was not the case. These involved stainless steel bonded to the torlon (metal to torlon bonds meant to simulate the effect of the bond on the metallized portion of the actual substrates). I was unable to pry the steel pieces from the torlon before they were cooled, but afterwards when I lightly pried up, the adhesive itself broke. It remained in contact with each material. In general, the metalized chips held somewhat better than did the plain ceramic pieces, but still never near $100 \%$ success with any test using these adhesives. Of course they are only meant for temperature ranges of -65 to $275^{\circ} \mathrm{F}$. We initially concluded that the smooth surface of the aluminum nitride may have been responsible for the tendency of the bond to fail at the adhesive to AlN interface, but later samples arriving with a rougher surface had no apparent difference in success. It may be reasonable to assume that the adhesive tends to want to shrink at or above the rate of the torlon, but the metal and the AlN tend to shrink less than does the torlon. This may have the effect of causing the adhesive to pull away from the substrate or metal. I have no other theories to offer for the behavior of these adhesives and can only say that it tends to be consistent.

One type of adhesive that had little expectation of succeeding was the cyanoacrylate esters, commonly referred to as superglues. They had ideal drying times, but the adhesive tended to have a low survival rate. About $25 \%$ (perhaps a little less) survived the cooling. The cold is clearly too much for these. In every failure with these adhesives, the adhesive bond sheared within itself, in contrast to most of the acrylics. These adhesives have always been known for their brittleness. The strong bonding between the adhesives and the bonded materials may have led to the breakage in the middle when the torlon tended to shrink more than the other material. 
Two part epoxies are made in many forms, and I tested several. The Devcon 5 minute epoxy did not work particularly well (it did not set in 5 minutes either) nor did the Conap Easypoxy. Ciba-Geigy Araldite and Tra-Con Tra-Bond 2151 epoxies both worked well with all AlN samples staying put in the cryostat during the cooling cycle. In order to punish these bonds with far greater temperature dropping rates than they would ever see, I quenched them in liquid nitrogen. The acrylics and superglues had no survivers in this type of test, but with the last two epoxies through about a dozen quenches only one aluminum nitride sample failed, and I had to pry quite hard to break it off. I was unable to remove the remainder of the AlN samples even when I tried, and for the Tra-Con this amounted to a success rate of above 90\%. There appeared to be no considerable difference between the samples that had cured with heat and those cured at room temperature. The other samples that I pried off after the $\mathrm{LN}_{2}$ quench were some of the Si samples and the SiC; they had a $0 \%$ success rate with the other adhesives and about 50\% here. The long pot life of these epoxies make them very attractive, especially the Tra-Con because it is known to pass NASA outgassing specs, but the extremely long setting time is a problem.

I have also been unable to remove the samples glued together with $3 \mathrm{M} 3535$ $\mathrm{B} / \mathrm{A}$ Scotch Weld urethane. I have been unable to pry anything off using this adhesive even after a couple dozen $\mathrm{LN}_{2}$ quenches. To this time, I have only found one major problem with using this adhesive; without heat it requires about 15 to 20 minutes to setup completely and that is the approximate pot life at room temperature. Even with heat, the pot life is very short in comparison to the 4 to 6 minute setting time. (The glue is only workable for about 10 minutes at ambient temperatures.) Again, there does not appear to be any difference in performance between adhesives cured with heat and those cures without since no samples ever came loose. I believe the inherent flexibility of this material is why it is so tough at low temperatures. I have not yet found any companies making urethanes that have any experience at liquid helium temperatures, but perhaps such a company does exist.

One final attempt to improve the performance of the acrylics was the use of Union Carbide organofunctional silanes to improve the adhesion between the acrylic and the stainless steel. My tests were not particularly conclusive, because I could see no apparent difference between those samples using the silanes and those not using the silanes. It is possible that there is no improvement in performance of acrylics with this substance. 


\section{glue summary 1}

\begin{tabular}{|c|c|c|c|c|c|}
\hline \multicolumn{6}{|c|}{ AdI } \\
\hline Adhesive Name & Type & Set Time & Pot Life & Tests Run & Notes \\
\hline $\begin{array}{l}\text { Loctite } \\
\text { Litetak } \\
376 \text { and } 7 \text { EN484 }\end{array}$ & UV-cure & $=30 \mathrm{~s}$ with UV & Negligible & $\begin{array}{l}2 \text { separate samples } \\
4 \text { C.F.C. cooldowns } \\
\text { Fiber damage test }\end{array}$ & $\begin{array}{l}\text { Used most in lab } 6 \\
\text { fiber connectivity } \\
\text { work }\end{array}$ \\
\hline $\begin{array}{l}\text { Master Bond } \\
1 \text { Coponent } \\
\text { UV } 15-7\end{array}$ & UV-cure & $\approx 30 \mathrm{~s}$ with UV & Negligible & $\begin{array}{l}2 \text { separate samples } \\
4 \text { C.F.C. cooldowns } \\
\text { Fiber damage test }\end{array}$ & \\
\hline $\begin{array}{l}\text { Norland } \\
\text { Optical Adhesive } 61\end{array}$ & UV -cure & $=30 \mathrm{~s}$ with UV & Negligible & $\begin{array}{l}2 \text { separate samples } \\
4 \text { C.F.C. cooldowns } \\
\text { Fiber damage test }\end{array}$ & \\
\hline $\begin{array}{l}\text { Loctite } \\
\text { Speed Bonder } 324\end{array}$ & 2 part acrylic & $\begin{array}{l}2 \text { to } 5 \mathrm{~min} . \\
\text { (also } 2-5 \mathrm{~min} \\
\text { primer wait) }\end{array}$ & Negligible & $\begin{array}{l}2 \text { separate samples } \\
4 \text { C.F.C. cooldowns } \\
\text { Fiber damage test }\end{array}$ & \\
\hline $\begin{array}{l}\text { Permabond } \\
\text { Quick Bond } 610\end{array}$ & 2 part acrylic & 2 to $5 \mathrm{~min}$ & Negligible & $\begin{array}{l}2 \text { separate samples } \\
4 \text { C.F.C. cooldowns } \\
\text { Fiber damage test }\end{array}$ & \\
\hline
\end{tabular}

Conclusions: Each adhesive in this category performed approximately the same.

For this application, the single component UV adhesives are more convenient to use and are less messy.

If they do not cause any damage to the fibers (none was seen with the unassisted eye), they should be used. 


\begin{tabular}{|c|c|c|c|c|c|}
\hline Adhesive Name & Type & $\begin{array}{l}\text { Substrate to } \mathrm{T} \\
\text { Set Time }\end{array}$ & $\begin{array}{l}\text { Torlon Adhesi } \\
\text { Pot Life }\end{array}$ & $\begin{array}{l}\text { ive tests } \\
\text { Tests Run }\end{array}$ & Notes \\
\hline $\begin{array}{l}\text { Loctite } \\
\text { Speed Bonder } 324\end{array}$ & 2 part acrylic & $\begin{array}{l}2 \text { to } 5 \mathrm{~min} . \\
\text { (also } 2-5 \mathrm{~min} \\
\text { primer wait) }\end{array}$ & Negligible & $\begin{array}{l}\mathrm{AIN}, \text { and aluminum } \\
\mathrm{SiC} \text {, and } \mathrm{Si} \\
\text { To Torlon }\end{array}$ & $\begin{array}{l}\text { Two glue tests. } \\
\text { About } 25 \% \text { success } \\
\text { on first cooldown }\end{array}$ \\
\hline $\begin{array}{l}\text { Permabond } \\
\text { Quick Bond } 610\end{array}$ & 2 part acrylic & 2 to $5 \mathrm{~min}$ & Negligible & $\begin{array}{l}\mathrm{AIN}, \text { and alumina } \\
\mathrm{SiC} \text {, and } \mathrm{Si} \\
\text { To Torlon }\end{array}$ & $\begin{array}{l}\text { Three glue tests } \\
50 \% \text { on each run }\end{array}$ \\
\hline $\begin{array}{l}\text { Devcon } \\
5 \text { minute epoxy }\end{array}$ & $\begin{array}{l}2 \text { part epoxy } \\
\text { quick setting }\end{array}$ & $\begin{array}{l}\text { supposed to b } \\
5 \mathrm{~min}\end{array}$ & 1 to $2 \mathrm{~min}$ & $\begin{array}{l}\text { AIN to Torlon } \\
1 \text { test only }\end{array}$ & $\begin{array}{l}\text { Did not set in } 5 \mathrm{~min} \\
\text { Bond failure cold }\end{array}$ \\
\hline $\begin{array}{l}\text { Conap } \\
\text { Easypoxy }\end{array}$ & 2 part epoxy & $\begin{array}{l}2 \text { hours } \\
\text { full cure } 24 \mathrm{~h}\end{array}$ & $30 \mathrm{~min}+$ & $\begin{array}{l}\text { AIN to Torlon } \\
1 \text { test only }\end{array}$ & $\begin{array}{l}\text { Good worklife } \\
\text { Bond failure cold }\end{array}$ \\
\hline $\begin{array}{l}\text { Permabond } \\
910 \text { Industrial } \\
\text { General Adhesive } \\
\end{array}$ & \begin{tabular}{|l|} 
alpha \\
cyanoacrylate \\
ester
\end{tabular} & $\begin{array}{l}0.5 \text { to } 1 \mathrm{~min} \\
\max \end{array}$ & None & $\begin{array}{l}\text { AIN and Alumina } \\
\text { to Torlon } \\
2 \text { cold test } 1 \text { quench }\end{array}$ & $\begin{array}{l}=25 \% \text { init. cooldown } \\
\text { survival } 0 \% \text { quench } \\
\text { shears within glue }\end{array}$ \\
\hline $\begin{array}{l}\text { Loctite } \\
\text { Super Bonder } 498\end{array}$ & $\begin{array}{l}\text { alpha } \\
\text { cyanoacrylate } \\
\text { ester }\end{array}$ & $\begin{array}{l}0.5 \text { to } 1 \mathrm{~min} \\
\max \end{array}$ & None & $\begin{array}{l}\text { AIN and Alumina } \\
\text { to Torlon } \\
3 \text { cold test } 1 \text { quench }\end{array}$ & $\begin{array}{l}\text { also about } 25 \% \text { c.t. } \\
1 \text { survives quench } \\
\text { and cold tests }\end{array}$ \\
\hline $\begin{array}{l}\text { Tra-Con } \\
\text { Tra-Bond } \\
\text { BB-2151 } \\
\end{array}$ & 2 part epoxy & $\begin{array}{l}45 \text { min- } 1 \mathrm{hr} \\
\text { n o heat, } \\
10 \text { min heat }\end{array}$ & 45 min. typ & $\begin{array}{l}\text { AIN, SiC, Si to Torion } \\
3 \text { cold tests several } \\
\text { quench }\end{array}$ & $\begin{array}{l}\text { All AIN samples stay } \\
\mathrm{SiC}+\text { Si off in quench } \\
\text { passes NASA outgas }\end{array}$ \\
\hline $\begin{array}{l}\text { Ciba-Geigy } \\
\text { Araldite }\end{array}$ & 2 part epoxy & $\mid \begin{array}{l}\text { approx } 2 \text { hours } \\
\text { no heat } \\
\text { (pkg says } 6 \text { h) }\end{array}$ & 45 to $60 \mathrm{~min}$ & $\begin{array}{l}\text { AIN to Torion } \\
3 \text { cold tests and } \\
\text { several quenches }\end{array}$ & $\begin{array}{l}\text { Everything stayed } \\
\text { put here }\end{array}$ \\
\hline $\begin{array}{l}3 \mathrm{M} \\
3535 \text { B/A } \\
\text { Scotch Weld } \\
\end{array}$ & $\begin{array}{l}2 \text { part } \\
\text { urethane }\end{array}$ & $\begin{array}{l}20 \text { min no } \\
\text { heat. with } \\
\text { heat } \approx 6 \text { min }\end{array}$ & 5 to $10 \mathrm{~min}$ & $\begin{array}{l}\text { AIN, SiC to Torlon } \\
3 \text { Cold tests and } \\
\text { several quenches }\end{array}$ & No Failures to date \\
\hline $\begin{array}{l}\text { Cotronics } \\
\text { Low Temp. pipe } \\
\text { seal, thread lock }\end{array}$ & $\begin{array}{l}\text { All purpose } \\
\text { adhesive }\end{array}$ & $5-10 \mathrm{~min}$ & & 1 cold test & . \\
\hline
\end{tabular}

Other adhesives testes included GC bond (rubber cement)

and other general epoxies.

Conclusions: The ideal adhesive does not exist, but several (such as the 3M 3535, Ciba-Geigy, and Tra-Con) are adequate. The epoxies have been frequently used to cryogenic temperatures and are a good choice, and the urethane is also a good choice due to its relative flexibility. 